\title{
Cost of Health Care, Economic Growth and Educational Outcomes in US Schools
}

\author{
M David Low ${ }^{\star}$ and Barbara J Low \\ The University of Texas School of Public Health, USA \\ *Corresponding author: M David Low, The University of Texas School of Public Health, USA, Tel: (713) 500-9435, E-mail: mdlow@shaw.ca \\ Received date: June 15, 2016; Accepted date: June 17, 2016; Published date: June 20, 2016
}

Copyright: () 2016 David LM, et al. This is an open-access article distributed under the terms of the Creative Commons Attribution License, which permits unrestricted use, distribution, and reproduction in any medium, provided the original author and source are credited.

\section{Editorial}

An exclusive focus on schools will not materially improve educational outcomes. The real problems confronting education and educators are a consequence of the chain of events that is triggered by the dramatic differences in people's social and economic circumstances across this vast and varied country. Test scores that typically are reported as national averages, and which are used to compare our children's abilities with those from other nations, obscure huge regional differences in student achievement. In reality students in some American states perform on a level with the best in the world while some perform at a level below almost any other developed country. A better understanding of why these differences exist, and persist, can point the way to effective and lasting interventions.

Not all children come to school with the same advantages. The differences between children that develop as they grow up in relatively enriched or impoverished circumstances, lead to vastly different levels of personal mastery, attitudes toward success, beliefs about education and abilities to learn before they ever get to school. Inequalities in these personal "spiritual" resources, in Nobel Laureate Robert Fogel's terms, are as important as material ones [1]. Our greatest concern should be for the inevitable consequences of not addressing the conditions that lead to these differences.

What are those consequences? There are many, but the most costly in both human and economic terms is perpetuation of disadvantage. Along with the loss of social capital, we pay a price in human suffering and the highest health care costs in the world. A great deal of research in the USA and elsewhere has shown that health status in a population follows a gradient that is a function of social position. Those on top not only enjoy higher incomes, they are also healthier than those who are less fortunate. The greater the differences in economic status, the greater the differences in health status. As the economic gulf widens, the health gulf widens. Ominously, income differences between the most well off and the least well-off in America are getting wider. This deepening and hardening of social stratification is a real threat to America's future. Because of strong evidence linking educational attainment to social position and a healthy life, we have worked to identify the personal and social determinants of educational success and health among children in America. Using NAEP data from state and district levels (National Assessment of Educational Progress, 2010) [2], and taking these standardized math and reading test scores of 4th and 8th-grade students as our initial measure of "success," we have found that he strongest correlations with test scores are factors that are specific to the students themselves, their parents or guardians and families, resources such as books and computers in their homes, teachers' experience, and personal and neighbourhood economic conditions. It is clear that an exclusive focus on school performance will miss most of the critical factors that lead to success for children, both in school and in life. The case of Washington, D.C., where they spend nearly twice as much per student as in Montana, for example, with significantly worse outcomes, shows that money alone, even large amounts of it, is not the answer either.

Strong evidence points to the fact that learning and education begins at birth, not in kindergarten. Even more importantly, a child's earliest life experiences are critical factors for brain development. Both positive and negative experiences have very long-lasting effects. We need to think of our common responsibilities for the education of our children in these terms and begin to create policies that reflect such understanding. As the Carnegie Foundation (1994) [3], has long said, what is really needed is a comprehensive and integrated model for optimal early childhood development, health, and education that can be applied in every community in America. The evidence suggests that a new policy, linking early child care with education, would result in significant improvement in the health of the American population while reducing health disparities and the income inequalities that breed social problems in all regions of the country. This expectation is supported by Günther Rehme (2001) [4], in a study of redistribution of personal incomes, education, and economic performance in OECD countries. His work showed that there is a negative relationship between income inequality and economic growth-less inequality, more growth-and that, in relatively wealthy countries, spending more on education would both enhance growth and decrease pre- and post-tax inequality. Rheme's work points to the possibility of achieving four highly desirable objectives together: a policy based on evidence from research on the social determinants of health and that integrates early child care and education, would not just strengthen educational attainment and the stock of human capital, but it would also improve overall health status, reduce income inequality, and promote economic growth. This possibility should be a sufficient incentive to engage the attention of policy makers throughout the country, whatever their usual domain of interest. Our country needs it and our children deserve it.

\section{References}

1. Fogel RW (1999) The Fourth Great Awakening and the Future of Egalitarianism. Chicago, University of Chicago Press.

2. National Assessment of Educational Progress (2010) US Department of Education.

3. Carnegie Corporation of New York (1994) Starting Points: Meeting the Needs of Our Youngest Children. The report of the Carnegie task force. New York, Carnegie Corporation of New York.

4. Rehme G (2001) Redistribution of Personal Incomes, Education and Economic Performance Across Countries Helsinki. World Institute for Development Economics Research. 